\title{
AUTHORITY AND INTERPRETIVE METHOD IN LUTHER'S APPROACH TO SCRIPTURE ${ }^{1}$
}

\author{
Mark Thompson
}

Martin Luther's approach to Holy Scripture remains controversial. Though most recognise his significance in the history of biblical interpretation, no genuine consensus has yet emerged concerning the basic elements of his approach. Attempts to portray him as the forefather of biblical criticism, an archetypal fundamentalist, and even a proto-existentialist, all attract trenchant criticism. The interests of the twentieth century repeatedly intrude and distort many reconstructions. In the commotion, Luther's own voice is often lost.

This thesis undertakes a fresh examination of Luther's approach to Scripture which gives particular attention to Luther's own words in their literary and historical context. It explores a series of connections in his thought, analysing his scattered statements in terms of four categories reflected in his own terminology: inspiration (inspiratio), unity (tota scriptura), clarity (claritas scripturae), and sufficiency (sola scriptura). In particular, it identifies those elements which enable Luther to move with confidence between his statements about the authority of Scripture and his interpretive method.

Chapter one surveys Luther's theological and exegetical inheritance. A theological, though deliberately pre-critical examination of the biblical testimony to its own origin, nature, and use, is followed by an outline of some of the most relevant developments in both the patristic and medieval periods. Luther was demonstrably a biblical theologian who did not shy away from making use of the contributions of Christian

\footnotetext{
${ }^{1}$ Mark D. Thompson, A Sure Ground on Which to Stand: The Relation of Authority and Interpretive Method in Luther's Approach to Scripture (unpublished D. Phil. thesis, University of Oxford, 1997); supervisor Dr Alister E. McGrath.
} 
thinkers who had gone before him. He always considered himself to be thoroughly orthodox.

In chapters two and three, Luther's statements about the origin of Holy Scripture are examined. Luther endorsed the view of Aquinas and others that God can be described not only as one who has spoken his Word, but as the author of that Word written as Scripture. He therefore spoke of God's involvement with Scripture in the most direct and intimate terms. However, he was also able to speak of the human element in its composition in a way that was meaningful. He was willing to identify Scripture as the Word of God (while recognising the other important uses of this expression), yet he could also speak of the literary choices made by Moses or Paul. The evidence of Luther's own statements from throughout his career as a teacher and pastor does not support the conclusions drawn by a number of studies on this subject.

Chapter three investigates Luther's explanation of biblical inspiration as the process by which this dual authorship was made possible. Luther believed this inspiration extended to the actual words of the text, not merely to its essential or doctrinal content. While Luther did not articulate a doctrine of verbal inspiration in the same form and detail as others both before and after him, many of the basic concerns of such a doctrine are demonstrably his concerns as well. Luther's commitment to the biblical text as the Word of God, brought about even in the particularities of its vocabulary, grammar, and syntax by both the Spirit of God and the human writers, carried important implications for his view of its authority and the interpretive methods he endorsed. At this point Luther's celebrated 'critical decisions' with regard to Scripture are examined in their context. The evidence leads us to conclude that the statements regularly cited in this connection do not prove what many try to prove with them.

Chapter four looks at Luther's understanding of the coherence or unity of the biblical text. Luther spoke regularly of 'all Scripture' or 'the entire Scripture'. He identified a unity pertaining to the canonical books which arises from their common authorship and is most evident in their common testimony to Christ. This was reinforced by a particular 
understanding of the law/gospel dynamic throughout both testaments. His particular insistence that the entire Scripture 'inculcates Christ (Christum treiben)' led him to new conclusions. Yet this actually raises other questions about his entire approach. Is Luther's identification of the centre of Scripture undermined by the way he marginalised parts which did not fit the pattern? Luther's treatment of the Epistle of James, considered in detail in chapter three, is re-examined in the light of his comments on the unity of Scripture. Though his life-long struggle with this epistle cannot be denied, the circumstances and his own refusal to see a resulting tension in his approach to Scripture must also be taken seriously.

Chapter five explores Luther's insistence on the clarity of Scripture. This has been a particular focus of interest in recent Luther scholarship. Luther affirmed Scripture's inherent intelligibility throughout his life. It was not simply a polemical device used against the scepticism of Erasmus in 1524 and 1525. In the indulgence disputes, the eucharistic debates, his tracts against the Jews and Turks, not to mention countless sermons and letters, he maintained that God had effectively communicated his mind in Holy Scripture.

The important question of precisely what is clear in Scripture according to Luther is addressed at this point. $\mathrm{He}$ understood clarity to pertain to the words of Scripture themselves. This raises further questions about the nature of Scripture as a translated text. However, Luther was far from naive in ascribing clarity to a text which in its original form was unintelligible to many. Indeed, his life-long commitment to the task of translating the Old and New Testaments arose from a conviction that Scripture is intelligible on its own terms and that every effort should be made to enable Christian men and women to engage directly with the text in their own language.

The final chapter investigates the meaning of the sufficiency of Scripture in Luther's writing. The evidence of his own statements as well as his interpretive practice will not allow us to conclude that the exegetical tradition was to be completely disregarded. Throughout his life Luther cited the Fathers and medieval doctors when it suited him. Nor may we conclude that he dispensed with human reason. He continued 
to value the study of logic as an aid to clear thinking and preaching. However, Luther considered that the Scriptures carried a unique authority, the authority of Christ himself, and that all other sources of theological knowledge can be endorsed only in so far as they conform to the truth found there. Here, once again, Luther was strongly influenced by his inheritance. Yet here, once again, Luther made a distinctive contribution.

The evidence reveals both continuity and development in approach to Holy Scripture. His commitment to its unique and final authority in matters of doctrine and life is demonstrable long before the indulgence controversy and is still present in his final lectures on Genesis. His conviction that the centre of Scripture is the person and work of Jesus Christ is likewise present throughout his life. Even the language of claritas scripturae cannot be restricted to one period of his life. Yet his early endorsement of the Quadriga gradually gave way to a greater stress on the grammatical sense of the text and its historical situation (though in an attenuated form allegory continued to feature in his expositions throughout his life). His early application of the 'letter and spirit' distinction was later replaced by the more productive 'law and gospel' dynamic which he developed from hints in Augustine. In addition, some change in his perspective on biblical books is evident in the light of his revision of a number of biblical prefaces later in life.

This thesis demonstrates the way four basic concepts form a bridge between Luther's statements about Scripture's authority and his interpretive method. Luther's confidence (confidentia) in calling all to submit to the teaching of Scripture and in explaining the content of that teaching arises from his understanding of its origin, nature, and use. He was convinced that Scripture is the Word of God, inspired, coherent, intelligible, and sufficient, and as such it must always stand over and above all the words of men. He was also convinced that this Word is to be understood on its own terms, with the expectation that God has coherently and clearly communicated himself and his purposes in it. As he told the Diet of Worms: 'my conscience is captive to the Word of God (capta conscientia in verbis Dei)'. 